\title{
The Use of Molecular Markers (p16, Ki-67 and E-Cadherin) in Uterine Cervical Biopsies
}

\author{
Natália Gaspar Munhoz, Damaris Aparecida Rodrigues, Juliana Figueiredo Pedregosa, \\ Juliana Olsen Rodrigues, Melissa Silva Garcia Junqueira, Patrícia Tiemi Kamiya Yonamine, \\ Sabrina Fontanele Pereira, Simone Uezato, Thiago Pandossio, Elaine Keid Leso Martins, \\ Flavia Borges de Oliveira, Jose Antonio Cordeiro, Jane Lopes Bonilha and Patrícia Maluf Cury*
}

São José do Rio Preto Medical School, São Paulo, Brazil

\begin{abstract}
Introduction: Cervical cancer is related to the Human Papillomavirus (HPV). The E7 viral DNA sequence induces the start of DNA synthesis of infected cell, releasing protein p16. The sequence E6 inhibits apoptosis, with prolonged survival of cells heavily damaged and changed, with inhibition of p53 protein and increasing of protein Ki-67. In those injured cells, the molecules are reduced to join the cell membrane, the type E-cadherin.

Aim: To study the expression of p16 protein in: normal epithelium cervical, cervical lesions, pre-invasive (CIN) persistent and no persistent lesions and invasive carcinoma of the cervix and to correlate with the expression of Ki-67 and Ecadherin.

Patients and Methods: 54 uterine cervix biopsies were selected and submitted to immunohistochemical study, with biomarkers p16, Ki-67 and E-cadherin.

Results: 1 CIN I (27.9\%) and CIN II (47.9\%) had lower expression of p16 than in CIN III (73.5\%) and invasive carcinoma $(72.7 \%)(\mathrm{p}<0.0005)$. For Ki-67, invasive carcinoma $(57.8 \%)$, had a higher expression when compared to CIN I (35.6\%), CIN II $(51.9 \%)$ and CIN III $(40.9 \%)(p=0.005)$. E-cadherin expression in invasive carcinoma $(46.2 \%)$ was lower than in CIN III $(56.0 \%)$, CIN II $(77.4 \%)$ and CIN I $(82.2 \%)(p<0.0005)$ and, normal epithelium had the greatest E-cadherin expression $(89.1 \%)$. In persistent and no persistent CIN there was no difference in the expression of the biomarkers, with p16 presenting $\mathrm{p}=0.50, \mathrm{Ki}-67, \mathrm{p}=0.91$ and the E-cadherin a $\mathrm{p}=0.43$ value.

Conclusions: The use of p16, Ki-67 and E-cadherin biomarkers in cervical biopsies with difficult diagnosis could help in the early diagnosis of malignant lesions and support adequate treatment, 2 . There is no association between the diagnosis of the biopsy and the persistence of the cervical lesion and, 3. The used biomarkes don't differentiate between persistent $\mathrm{CIN}$ and no persistent lesions.
\end{abstract}

Keywords: p16, ki-67, E-cadherin, uterine cervical cancer, persistent cervical intraepithelial neoplasia.

\section{INTRODUCTION}

Epidemiological evidence shows that breast and genital cancers are the most frequent cancers among women worldwide [1]. It is estimated that around 500,000 women per year develop cancer of the uterine cervix worldwide. In Brazil, the National Cancer Institute (INCA), estimates, for 2008 and 2009, approximately 466,730 new cases per 100,000 inhabitants. In our country, cancer of the cervix is the second most common malignancy among women with an estimate of 19,000 new cases following only to breast cancer, and is the fourth cause of death by cancer in women [2].

The epidemiological profile of the disease shows that it is related to sexual activity, and associated to HPV infection [3]. The high risk HPV types 16 and 18 are the most prevalent, representing $59.8 \%$ and $15 \%$, respectively, in cases of

*Address correspondence to this author at the Faculdade de Medicina de São José do Rio Preto, Av. Brigadeiro Faria Lima 5416 CEP 15090-000, São José do Rio Preto - São Paulo, Brazil; Tel/Fax: +5517-3201-5056; E-mail: pmcury@hotmail.com invasive cancer $[4,5]$. A persistent high-risk HPV infection is considered not only a risk factor, but also as a prerequisite for the development of cervical cancer [6].

Recent studies show that the presence of HPV DNA in more than $99.7 \%$ of cases of cervical intraepithelial neoplasia (CIN) used the technique of polymerase chain reaction (PCR). It is well established that HPV infection is the central and causal factor of cervical cancer [4]. Risk factors such as age of initiation of sexual activity, number of sexual partners, number of children, smoking, low socio-economiccultural status and dietary deficiency of some elements are part of the natural history of this disease [1].

Therefore, cervical cancer represents a real public health problem, and is directly linked to the degree of underdevelopment of countries. It is one of the best examples of a cancer that can be prevented. Knowledge of the natural history of cervical cancer, which usually presents with a relatively slow progression, and the widespread use of screening methods for the detection of precursor and early stage lesions have permitted efficient secondary prevention in recent decades. Currently, primary prevention, through the use of vac- 
cines against human Papillomavirus (HPV) has been demonstrated [4, 7-9].

According to World Health Organization (WHO, 2008) [10] classification of the cervical uterine tumor, the precursor lesions of cervical cancer are classified as CIN I, CIN II and CIN III. Because there is a difficulty in diagnosis of such precursors, they can also be referred to as high and low grade lesions. However, sometimes in small biopsy it is quite difficult to differentiate lesions of low and high grade, and this diagnosis is very important to patient's treatment.

\section{Protein P16}

Several studies have highlighted the role of p16 as a marker of cervical carcinoma P16 expression is associated with the progression of disease and is directly related to the presence of HPV [4,7,11,12].

P16 belongs to the group of cyclin-dependent kinase $\mathrm{Cdk} 4 / 6$ inhibitors and is encoded by tumor suppressor gene $I N K 4 a$. Gene INK4a plays an important role in the regulatory pathway $\mathrm{Cdk}-\mathrm{Rb}-\mathrm{E} 2 \mathrm{~F}$. The product of this gene, p16INK4a, prevents $\mathrm{pRb}$ phosphorylation by inactivating Cdk4/6; $\mathrm{pRb}$ keeps on binding E2F transcription factors and as a result cells stay in G1 phase and do not pass to DNA replication. In cervical lesions induced by HPV, viral oncoprotein E7 interacts with $\mathrm{pRb}$ and inactivates it. As a result, the regulatory pathway $\mathrm{Cdk}-\mathrm{Rb}-\mathrm{E} 2 \mathrm{~F}$ is disrupted and inactivated $\mathrm{pRb}$ passes the cell cycle checkpoint $\mathrm{G} 1 / \mathrm{S}$ without any obstacle. As a response, an overexpression of p16 occurs. In turn, p16INK4a protein can be a marker of premalignant and malignant cervical epithelium cells. Functionally active gene $R B$ is shown to be able to negatively regulate the expression of INK4a on a transcriptional level, but the details of this negative feedback loop are still obscured [13-17].

In short, p16 expression, which can be detected immunohistochemically, is directly related to the presence of HPV [8]. Thus, this protein can be used as a biomarker that can add significant diagnostic precision in the assessment of CIN lesions [7, 12].

\section{Ki-67}

The Ki-67 is a marker of protein, non-histonic of cell proliferation, and is expressed in all phases of the cell cycle, except in G0 [18, 19]. This protein has a function of growth in human tumor, and expression of its marker could suggest the degree of malignancy [20-22].

The interaction of E6 and E7 HPV DNA in the host cell disturbs the cell cycle, expressing themselves by the abnormal expression of proteins, including the Ki-67 [13].

Some studies have shown that the Ki-67 immunohistochemistry positivity demonstrates the increasing proliferation in low and high grades of intraepithelial lesions [23]. In others, the results of analysis are consistent with a strong relationship between $\mathrm{Ki}-67$ and $\mathrm{p} 16$, in the recognition of HPV-associated pre-invasive cervical lesions [13].

\section{E-Cadherin}

Cadherins are glycoproteins of 120 to $130 \mathrm{kDa}$ that are involved in the cell adhesion and received this name due to the need of calcium $(\mathrm{Ca})$ in order to link to them. The firm intercellular adhesion attributed to the function of adhesive interactions plays a crucial role in tissue formation, since its involvement consists of an important biomarker for tumor development [24-28].

The squamous cells of cervix epithelium are strongly attached to each other and to the basement membrane through a large number of molecules of adhesion. Thus, ECadherin is one of the key molecules of adhesion that define the architecture and differentiation of keratinocytes in that epithelium. It is known that in intra-epithelial cervical cancer, there is a change in the expression of these molecules [25].

This suggests that the decrease or loss of expression of Ecadherin can be correlated with aggressive behavior and progression of cancer [24]. Roa et al. [29] consider Cadherins as the most important mediators of cell adhesion molecules and showed that the loss of this molecule in tumor tissues lines determines the ability to invade the collagen of tissues.

It is presumed that this down-regulation reduces the capacity of cells to adhere each other and facilitates their shutdown of primary tumor and metastasis. Therefore, the decrease in the expression of E-cadherin seems to be a useful parameter in evaluating the potential for malignancy of cervical cancer [24].

Dursun et al. [30] concluded that reduced expression of E-cadherin is significantly associated with overall survival and disease-free survival in the patients with cervical carcinoma, serving as an indicator of aggressive clinical behavior and could suggest the use of adjuvant therapy in early stages of the disease.

\section{Histological Diagnosis}

Although there are histological criteria for the diagnosis of cervical lesions [31], it is often vulnerable due to the size of the sample, and thus undermining the subsequent clinical conduct. As the cost of immunohistochemical study is cheaper than PCR for HPV, it would be interesting to find immunomarkers for different degrees of CIN. Thus, the aim of our work is to study the immunohistochemical expression of p16, Ki-67 and E-cadherin proteins in benign lesions, preinvasive and invasive carcinoma of uterine cervix, and to correlate the expression of these markers together in the cases with difficult interpretation, to help in diagnosis and prognosis of cervical lesions.

\section{MATERIAL AND METHODS}

\section{Samples}

Prior to the beginning of this work, this study was approved by the Research Ethics Committee of the FAMERP, file number 001-000494/2007, following the legal procedures.

Women submitted to cervical biopsies between 2004 and 2007 were selected. We evaluated the morphological changes in histological sections stained by hematoxylin and eosin (HE), according to the severity of cervical lesion (normal cervix, with CIN I, II or III and with invasive carcinoma of the cervix). Immunohistochemical study was performed for $\mathrm{p} 16, \mathrm{Ki} 67$, and E-cadherin. 
The immunohistochemistry technique for E-cadherin (NCL-E, Novocastra, clone 36B5), Ki-67 nuclear antigen (NCL-Hi-67, MM1, Novocastra) and p16 (NCL-p16 - 432, Novocastra) was then used and has been summarized as it follows: the $4 \mu \mathrm{m}$ cuts were dew axed, underwent antigenic recuperation, suffered peroxidase block and then were incubated into primary antibodies: ki-67 antigen mouse monoclonal antibody, dissolved in $1: 600$, the cadherin-E mouse monoclonal antibody dissolved in $1: 200$ and the p16 mouse monoclonal antibody dissolved in $1: 50$. The incubation with the biotinylated anti-Ig antibody or secondary antibody was used, which is specific for animal species, whose primary antibody was made (kit DAKO LSAB-labeled streptavidin biotin) for Ki-67 and cadherin-E, and for p16, secondary antibody was used (kit NOVOLINK-Polymer Detection Systems), dissolved in PBS for 30 minutes at $37^{\circ} \mathrm{C}$ in a humid room. Next, stretavidin biotin peroxidase complex incubation was made (Kit, peroxidase-DakoCytomation, Carpinteria, CA, USA). For the revelation, the cromogenic_diaminobenzine subtract was used and was stained with hematoxylin of Harris.

\section{Quantification of Immunohistochemical Results and Statistical Analysis}

To evaluate the marker positivity, we counted at least 500 cells per case, in a blind manner. Positivity was nuclear for $\mathrm{Ki}-67$, nuclear and cytoplasmic for $\mathrm{p} 16$, and cytoplasmic membrane for E-cadherin in light microscopy, with a magnification of $400 \times$. We made a quantification of the results by determining the index of positivity (number of cells marked by the antibody (p16, Ki-67 or E-cadherin) divided by the number of cells counted per sample.

Through the patients' electronic handbook, we selected 12 cases that presented persistence of the lesion in the last four years (April of 2003 to March of 2007), followed by periodic biopsy and/or cervical Pap smear. We compared these patients' initial diagnoses with the group of eight patients that didn't present recurrence of the disease in the same period of time, followed by cytological examination.

Statistical analysis was made with the use of nonparametric tests (Median, ANOVA and tabled statistics).

\section{RESULTS}

The 54 selected biopsies were classified as normal epithelium ( 5 cases), 12 cases of CIN I, 12 of CIN II, 13 of CIN III or squamous cell carcinoma in situ, and 12 cases of invasive squamous cell carcinoma of the uterine cervix (SCC).

The women's age ranged from 22 to 90 years, with an average of 45.74 years (median $=45$ ). Figs. (1-5) show examples of hematoxylin and eosin stain, and p16, Ki-67 and E-cadherin positivity in different diagnosis.

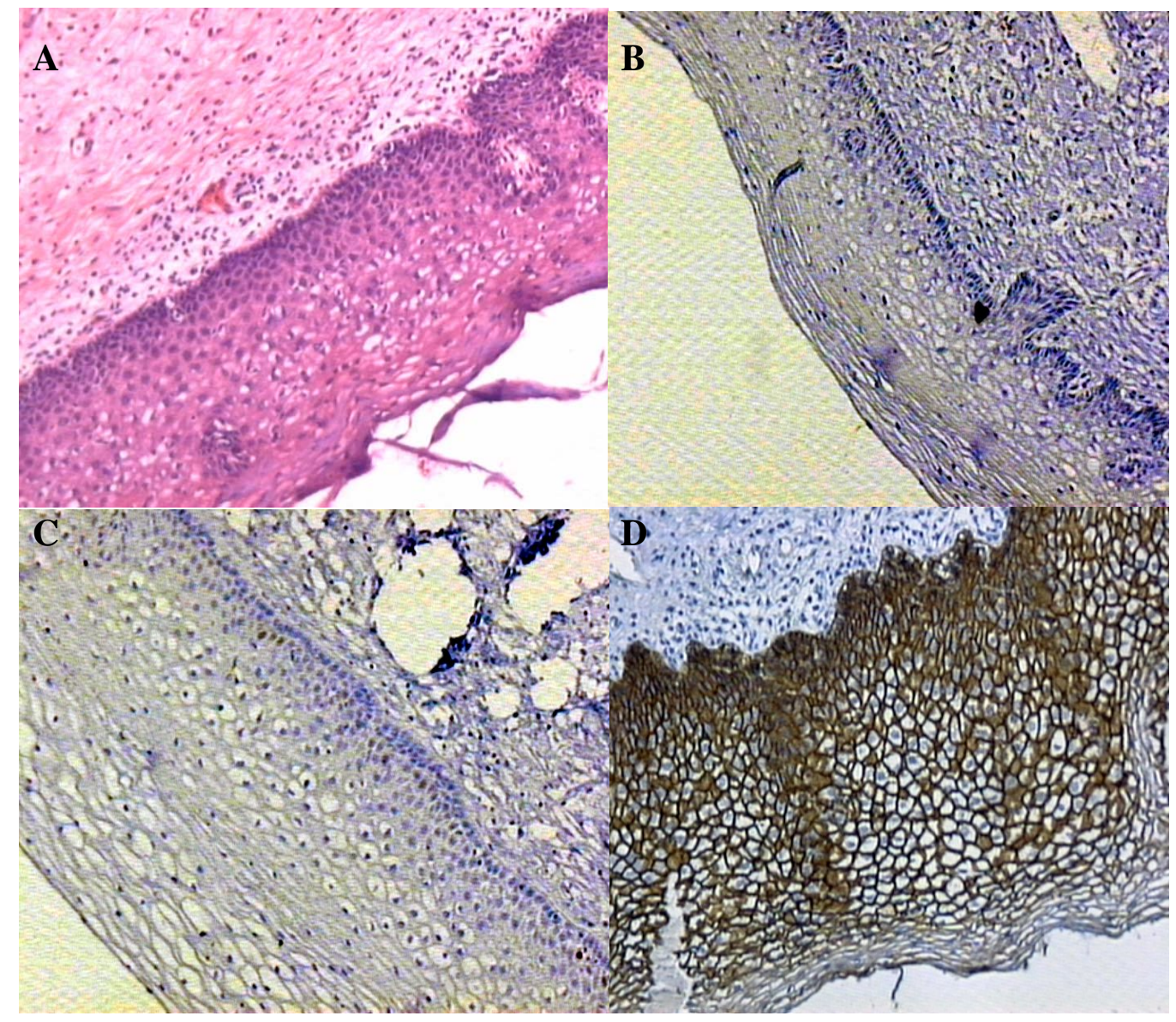

Fig. (1). Photomicrography of normal uterine cervix: (A) HE stain (100X); (B) p16 antibody (100X); (C) Ki-67 antibody (100X) and (D) Ecadherin antibody $(100 \mathrm{X})$. The number of positive cells for E-cadherin had the greatest expression $(89.05 \%)$ when compared with the cervical lesions. There was no p16 expression and a low positivity for Ki-67 (6.6\%). 


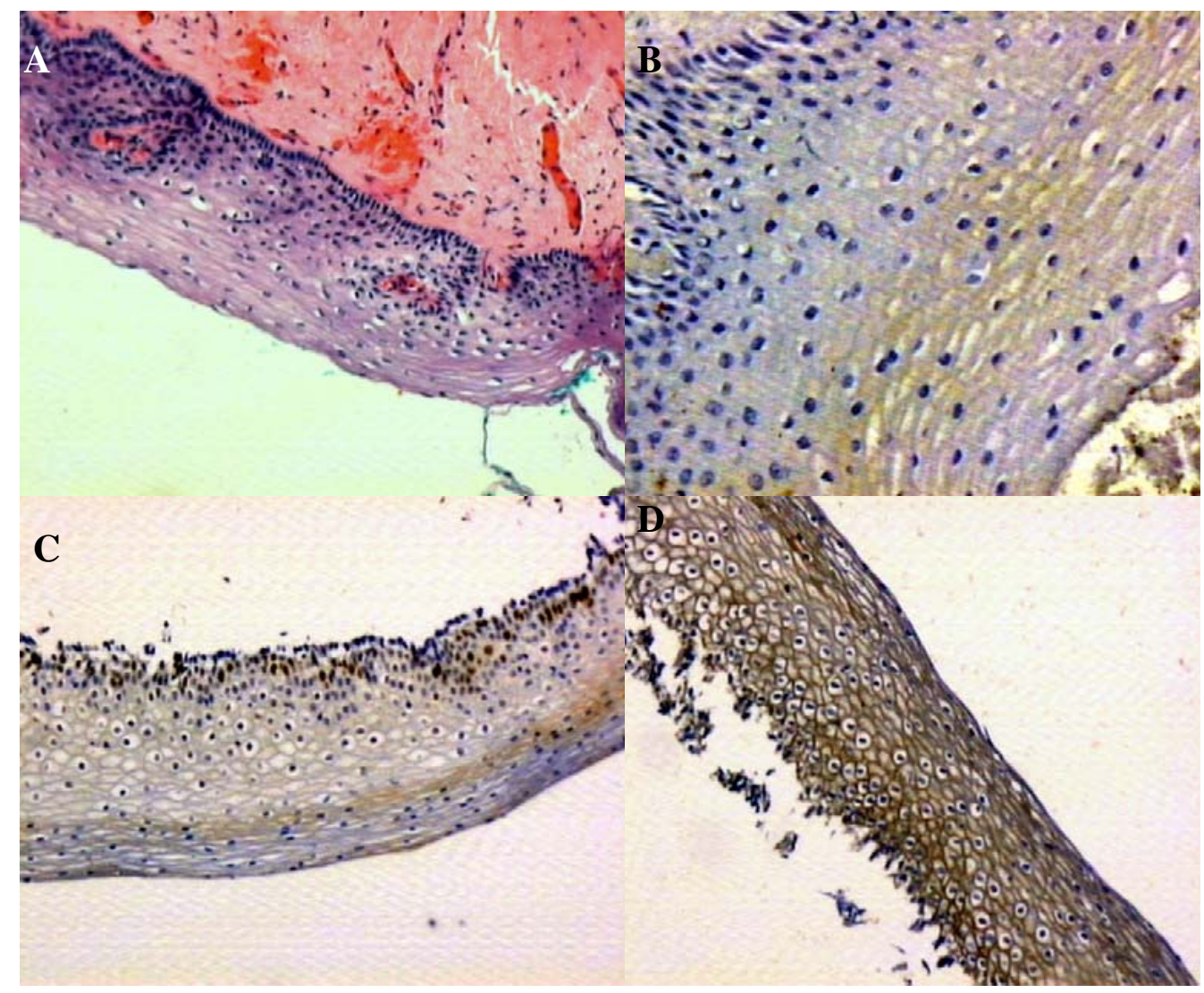

Fig. (2). Photomicrography of CIN I (Cervical intraepithelial neoplasia grade I): (A) HE stain (100X); (B) p16 antibody (200X); (C) Ki-67 antibody (100X) and (D) E-cadherin antibody (100X). The number of positive cells for p16 (27.94\%) and Ki-67 (35.6\%) was lower than for E-cadherin (82.18\%).

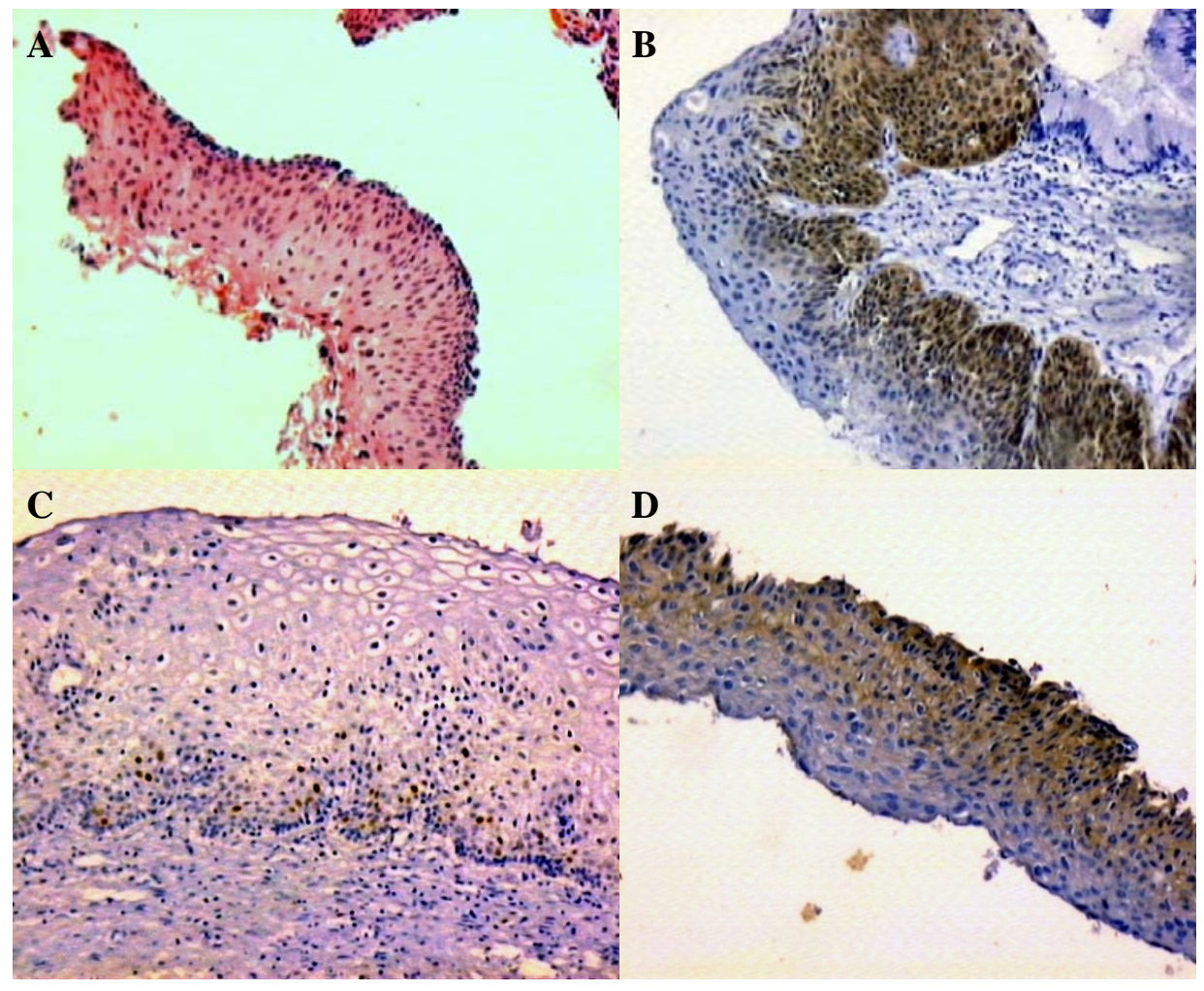

Fig. (3). Photomicrography of CIN II (Cervical intraepithelial neoplasia grade II): (A) HE stain (100X); (B) p16 antibody (100X); (C) Ki-67 antibody (100X) and (D) E-cadherin antibody (100X). The antibody E-cadherin had a higher expression (77.39\%) when compared with p16 $(47.93 \%)$ and $\mathrm{Ki}-67$ (51.9\%). 


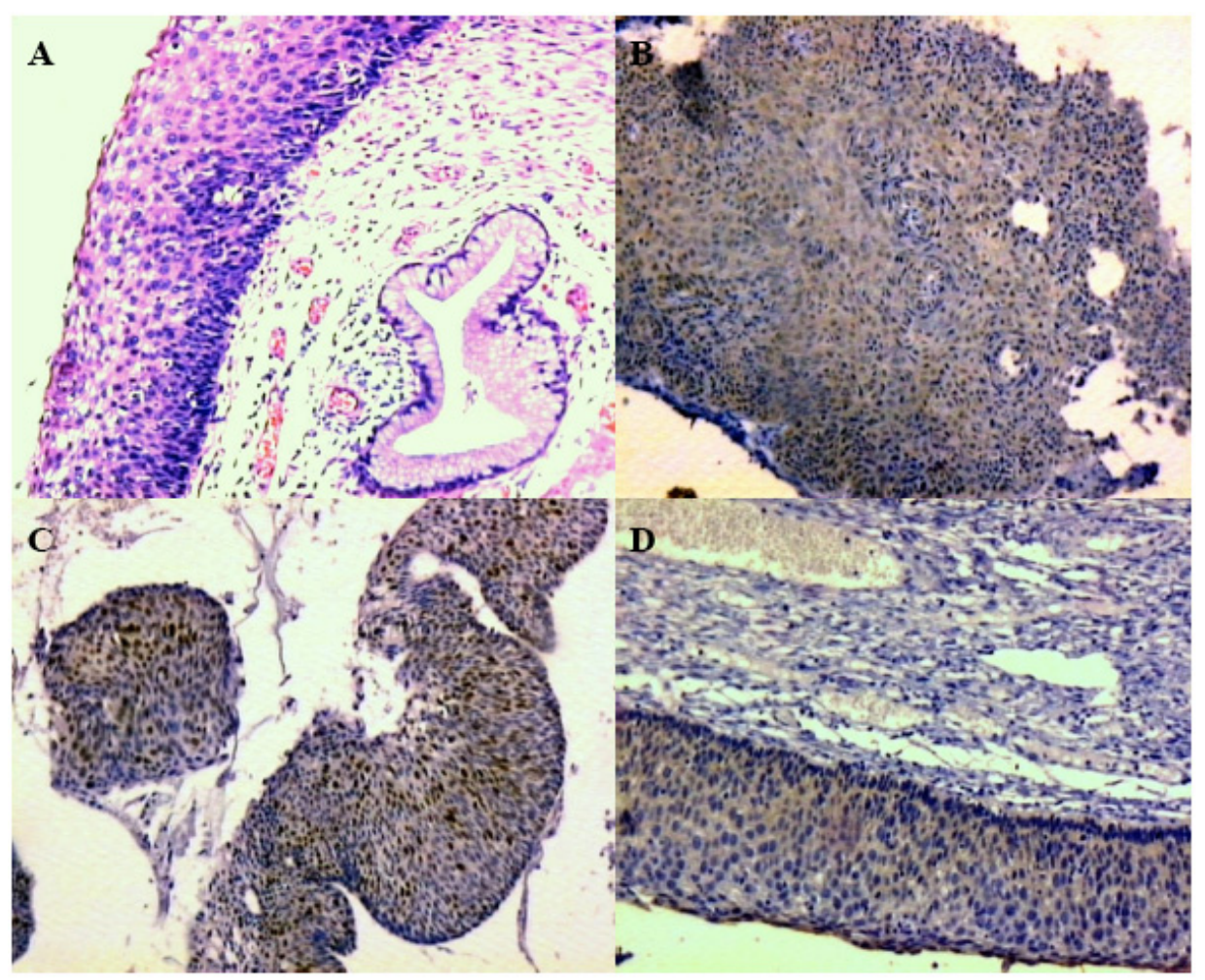

Fig. (4). Photomicrography of CIN III (Cervical intraepithelial neoplasia grade III): (A) HE stain (100X); (B) p16 antibody (100X); (C) Ki67 antibody (100X) and (D) E-cadherin antibody (100X). The antibody p16 had a higher expression (73.47\%) when compared with Ki-67 $(40.9 \%)$ and the E-cadherin (55.96\%).

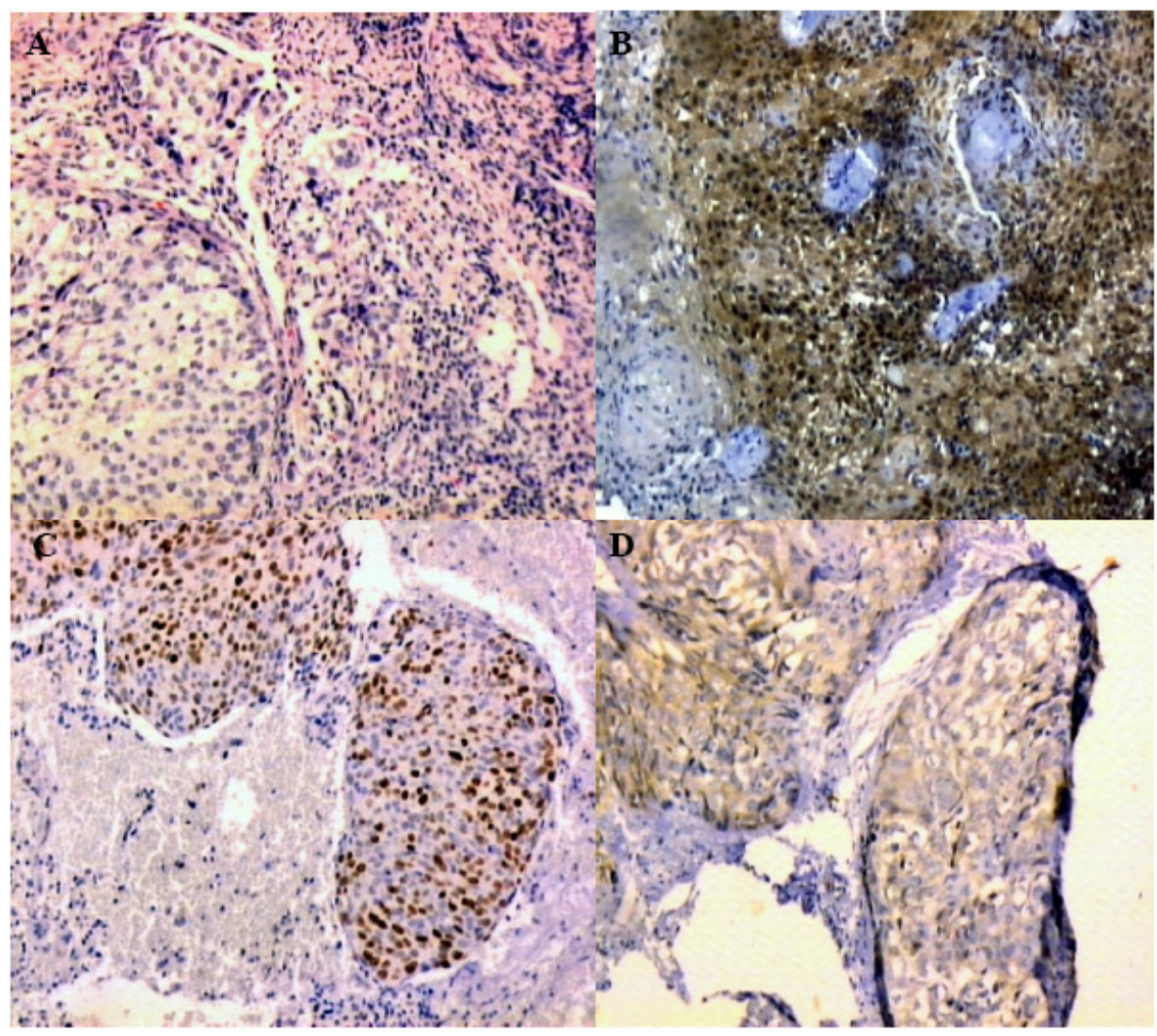

Fig. (5). Photomicrography of Invasive Carcinoma: (A) HE stain (200X); (B) p16 antibody (100X); (C) Ki-67 antibody (100X) and (D) Ecadherin antibody (100X). The number of positive cells for E-cadherin (46.15\%) and Ki-67 (57.8\%) was lower than for p16 antibody $(72.70 \%)$. 


\section{P16 versus Diagnosis}

Fig. (6) shows the distribution of positivity for p16 in the different groups in order to compare with the diagnosis. The histological sections of normal uterine cervix showed no expression of $\mathrm{p} 16$.

Through ANOVA test, we observed a statistically significant difference between the average percentages in the groups. CIN I (27.94\%) and CIN II (47.93\%) presented expression of p16 lower than CIN III $(73.47 \%)$ and invasive carcinoma $(72.70 \%)(p<0.0005)$.

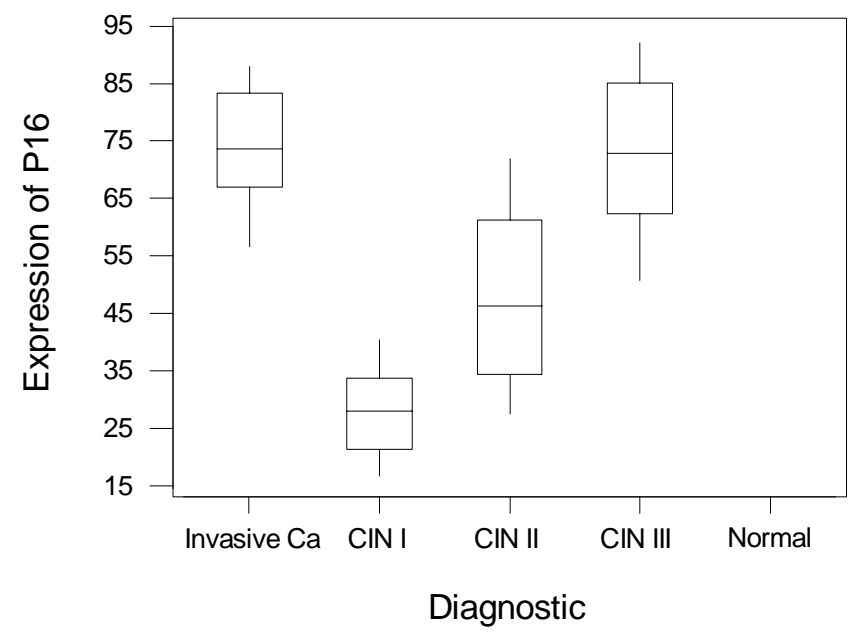

Fig. (6). Expression of p16 in different types of cervical lesion. There is an increase of p16 according to the degree of malignancy of injuries $(p<0.0005)$. Normal tissue did not present $p 16$ expression. Legend: CIN I - Cervical intraepithelial neoplasia grade I, CIN II - Cervical intraepithelial neoplasia grade II, CIN III - Cervical intraepithelial neoplasia grade III.

\section{Ki-67 versus Diagnosis}

Fig. (7) shows the different positivities to the Ki-67 evaluated in the groups. There was statistically significant difference only between the median for the normal group $(6.6 \%)$ with the neoplastic lesions. Invasive carcinoma (57.8\%), was highly positive for $\mathrm{Ki}-67$ when compared to CIN I (35.6\%), CIN II (51.9\%) and CIN III (40.9\%), but there was no statistically significant difference eas found between them $(\mathrm{p}=0.005)$.

\section{E-Cadherin versus Diagnosis}

Fig. (8) shows the distribution of expression of Ecadherin in groups (control and study), compared to the diagnosis.

Positivity for E-cadherin in the cases diagnosed with CIN III was the lowest observed among the pre-neoplastic lesions $(55.96 \%)$, whereas in cases of CIN I was $82.18 \%$, for CIN II, $77.39 \%$ and in the control group, $89.05 \%$. There was statistically significant difference when comparing the positive cases of invasive carcinoma (46.15\%) with CIN I and CIN II $(\mathrm{p}<0.0005)$.

\section{The Persistence of the Cervical Intraepithelial Neoplasia}

As for the persistence of the cervical intraepithelial neoplasia, we found in the 20 selected patients, $40.0 \%$ with diagnosis of CIN I, $30.0 \%$ of CIN II and $30.0 \%$ of CIN III.
We observed that there was no statistical correlation between the degree of CIN and the persistence of the lesion $(p=0.27)$ (Table 1).

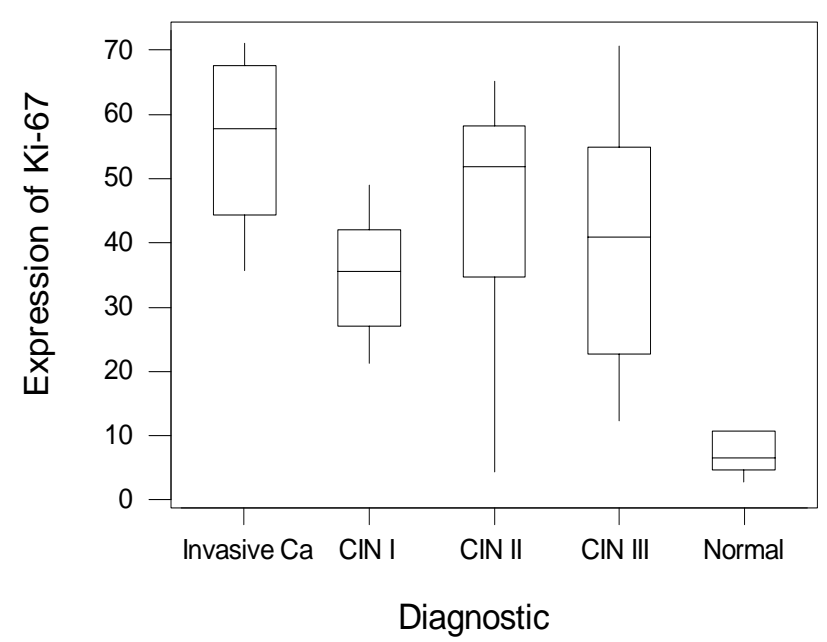

Fig. (7). Positive for Ki-67 in different types of injury of the uterine cervix. Ki-67 is higher expressed in neoplastic groups than in normal cervical biopsies $(p=0.005)$. Legend: CIN I - Cervical intraepithelial neoplasia grade I, CIN II - Cervical intraepithelial neoplasia grade II, CIN III - Cervical intraepithelial neoplasia grade III.

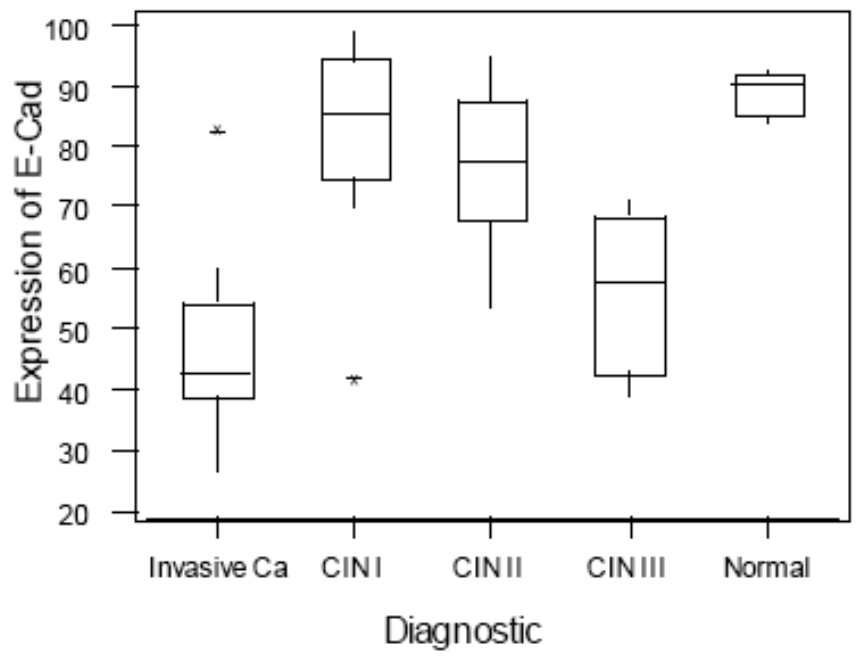

Fig. (8). Expression of E-cadherin in different types of injury of the uterine cervix. There was statistically significant difference when comparing the positive cases of invasive carcinoma (46.15\%) with CIN I and CIN II $(p<0.0005)$. Legend: CIN I - Cervical intraepithelial neoplasia grade I, CIN II - Cervical intraepithelial neoplasia grade II, CIN III - Cervical intraepithelial neoplasia grade III.

In persistent and no persistent CIN there was no difference in the expression of the biomarkers, with p16 presenting $\mathrm{p}=0.50, \mathrm{Ki}-67, \mathrm{p}=0.91$ and the E-cadherin a $\mathrm{p}=0.43$ value (data not shown).

\section{DISCUSSION}

In our study, we demonstrated an increased expression of the protein 16 from CIN I to invasive squamous cell carcinoma (SCC). For Ki-67 and E-cadherin, expression was direct and inversely related, respectively, with $\mathrm{p} 16$. This fact could help in the differential diagnosis between the lesions 
Table 1. Analysis of Biopsy for No Persistent and Persistent HPV in Different Types of Injury of the Uterine Cervix. There was No Statistical Correlation Between the Degree of CIN and the Persistence of the Lesion $(p=0.27)$

\begin{tabular}{|c|c|c|c|c|}
\hline \multirow[b]{2}{*}{ HPV } & \multicolumn{4}{|c|}{ BIOPSY } \\
\hline & CIN I & CIN II & CIN III & Total \\
\hline No Persistent HPV & 2 & 2 & 4 & 8 \\
\hline Row \% & 25,0 & 25,0 & 50,0 & 100,0 \\
\hline $\mathrm{Col} \%$ & 25,0 & 33,3 & 66,7 & 40,0 \\
\hline Persistent HPV & 6 & 4 & 2 & 12 \\
\hline Row \% & 50,0 & 33,3 & 16,7 & 100,0 \\
\hline $\mathrm{Col} \%$ & 75,0 & 66,7 & 33,3 & 60,0 \\
\hline Total & 8 & 6 & 6 & 20 \\
\hline Row \% & 40,0 & 30,0 & 30,0 & 100,0 \\
\hline $\mathrm{Col} \%$ & 100,0 & 100,0 & 100,0 & 100,0 \\
\hline
\end{tabular}

Single Table Analysis

$\begin{array}{ccc}\text { Chi-Square } & \text { df } & \text { p } \\ 2,6389 & 2 & 0,2673\end{array}$

Legend: CIN I - Cervical intraepithelial neoplasia grade I, CIN II - Cervical intraepithelial neoplasia grade II, CIN III - Cervical intraepithelial neoplasia grade III.

and may be a good marker to detect risk of developing cervical cancer in women infected by HPV.

All cases of SCC and CIN III in our study had an overexpression of p16. Similar evidence was obtained by Benevolo [11], Volgareva [31] and Tringler [32], which reported a greater expression of p16 in a large percentage of premalignant lesions and invasive SCC. Several studies have shown an increase in the expression of p16 protein in accordance to the degree of malignancy of lesions, showing to be a great marker specific for pre-malignant and malignant lesions $[4,32]$.

Moreover, our cases of normal cervix showed no expression of p16. Maehama and colleagues [33] reported that they found $10.6 \%$ of positive for HPV in women with normal cytology smear, using PCR technique. Based on that report, we expected to find some expression of p16 protein in this group of patients, which may not have happened because of the small number of cases studied, or non-viral integration in the genome of the host $[16,18]$.

In our study we observed that the associated use of biomarkers p16 and E-cadherin together is a good combination for diagnosis of cervical lesions. In respect to the use of Ki-67, there was no significant difference in invasive and pre-invasive lesions (CIN I, II and III). However, According to Kruse et al. [20], Ki-67 is a good diagnostic marker for CIN III, however, the reproducibility for CIN I and CIN II was not satisfactory. Our negative results could be due the small number of samples used in our study.

Several authors, such as Benevolo [12], Keating [13], Abeer [16], Volgereva [31], Tringler [32], Longato Filho [34] and Walts [35], showed similar results using these markers and concluding that p16 is the defining role in early detection of cervical cancer and $\mathrm{Ki}-67$ can be used as a factor of prognosis. For Keating (2001) [13], as far as Ki-67 is a good combination with 16 for diagnosis, E-cadherin expression also proved to be a substitute for Ki-67, supplementing the p16 marker for HPV in pre-neoplastic lesions and invasive cervical squamous carcinomas.
The median age of women in our study was 45.74 years, ranging from 22 to 90 years. Of these, $37(68.52 \%)$ had a diagnosis of pre-invasive lesions. It is known that the incidence of cancer of the cervix is usually at its peak age group increased slightly [2], which is consistent with data from other studies [3639].

The infection for HPV frequently happens and it ends quickly in most of the young women that begin sexual relationships, although HPV 16 persistent can progress to CIN III earlier than the non-persistent lesions [40]. Women that live below the poverty line have larger probability of being positive for HPV of high risk [41]. Many authors [42, 43] tell that in the persistent cases there is an association with HPV of high risk, what was not possible to evaluate in our work.

We did not perform the PCR test to study the HPV status in cervical lesions due to the high cost of this exam. However, p16 protein expression is considered a specific marker for this virus $[4,7]$ and can be used to differentiate patients with low grade lesions from others with high grade, that require a more aggressive treatment.

Although our work has shown similar results to those of international literature, there is no similar data with the Brazilian population using the three markers concurrently. Due to low cost, imunohistochemistry instead of PCR, is an economically feasible method, and thus can be easily performed in laboratory practice.

Thus, we suggest the use of biomarkers p16, Ki-67 and Ecadherin together to the diagnosis and prognosis of cervical lesions in order to help to differentiate lesions of low and high grade in difficult biopsies, but they are not helpful to differentiate between persistent and no persistent CIN.

\section{ACKNOWLEDGEMENT}

We thank the financial support from CNPq and CAPES.

\section{REFERENCES}

[1] Franco EL. Epidemiologia do câncer mamário ginecológico. In: Abrão FS. Sao Paulo, Eds. Tratado de Oncologia Genital e Mamária.. Roca, 1995. 
[2] Brasil. Ministério da Saúde. Secretaria de Atenção à Saúde. Instituto Nacional de Câncer. Coordenação de Prevenção e Vigilância de Câncer. Estimativas 2008: Incidência de Câncer no Brasil. Rio de Janeiro: INCA, 2008. [Cited on Oct. 4]. Available from: http://www.inca.gov.br/estimativa/2008/versaofinal.pdf [Accessed: March 2, 2008].

[3] Bauer HM, Hildesheim A, Schiffman MH, et al. Determination of genital human papillomavirus infection in low risk womem in Portland, Oregon. Sex Transm Dis 1993; 20(5): 274-8.

[4] Queiroz C, Silva TC, Alves VAF, et al. P16(INK4a) expression as a potential prognostic marker in cervical pre- neoplastic and neoplastic lesions. Pathol Pract Res 2006; 202: 77- 83.

[5] Psyrri A, DiMaio D. The human papillomavirus in cervical and headand-neck cancer. Nat Clin Pract Oncol 2008; 5(1): 24-31.

[6] Zampirolo JA, Merlin JC, Menezes ME. Prevalência de HPV de baixo e alto risco pela técnica de biologia molecular (Captura Hibrida II) em Santa Catarina. Rev Bras Anal Clin 2007; 39(4): 265-8.

[7] Von Knebel Doeberitz M. New markers of cervical dysplasia to visuale the genomic chaos created by aberrant oncogenic papillomavirus infections. Eur J Cancer 2002; 38(17): 2229-42.

[8] Soslow R, Isacson, C, Zaloudek C. Diagnostic immunohistochemistry of the female genital tract. In: Dabbs DJ, Ed. Diagnostic Immunohistochemistry. $2^{\text {nd }}$ ed. Churchill Livingstone: Philadelphia 2006.

[9] INCA. Neoplasias intra-epitelial cervical - NIC. Rev Bras Cancerol 2005; 46(4): 355-7.

[10] World Health Organization. World health organization classification of tumours. Pathology \& genetics-tumours of the breast and female genital organs. Lyon: IARC Scientific Publications, 2008; Vol. 4: p. 270.

[11] Guimarães MCM, Gonçalves MAG, Soares CP, Bettini JSR, Duarte RA, Soares EG. Immunohistochemical expression of p16 and bcl-2 according to HPV type and to the progression of cervical squamous intraepithelial lesions. J Histochem Cytochem 2005; 53(4): 509-16.

[12] Benevolo M, Mottolese M, Marandino F, et al. Immunohistochemical expression of p16(INK4a) is predictive of HR-HPV infection in cervical low-grade lesions. Mod Pathol 2006; 19(3): 384-91.

[13] Keating JT, Cviko A, Riethdorf S, et al. Ki-67, cyclin E, and p16INK4 are complementary surrogate biomarkers for human papillomavirusrelated cervical neoplasia. Am J Surg Pathol 2001; 25(7): 884-91.

[14] Branca M, Ciotti M, Santini D, et al. P16 (INK4A) expression is related to grade of cin and high-risk human papillomavirus but does not predict virus clearance after conization or disease outcome. Int $\mathrm{J}$ Gynecol Pathol 2004; 23(4): 354-65.

[15] renna SMF. Expressão proteica de P53 e C-MYC como marcadores no prognostico do carcinoma de colo uterino. [tese]. Campinas: Universidade Estadual de Campinas. Faculdade de Ciências Medicas, 2000.

[16] Bahnassy AA, Zekri ARN, Saleh M, Lotayef M, Moneir M, Shawki O. The possible role of cell cycle regulators in multistep process of HPVassociated cervical carcinoma. BMC Clin Pathol 2007; 7: 4.

[17] Howley PM, Lowy DR. Papillomaviruses and their replication. In: Knipe DM, Howley PM, Eds. Fields Virology, $4^{\text {th }}$ ed. Lippincott Williams \& Wilkins: Philadelphia, 2001; pp. 2198-29.

[18] Prowse DM, Ktori EN, Chandrasekaran D, Prapa A, Baithun S. Human papillomavirus-associated increase in p16INK4A expression in penile lichen sclerosus and squamous cell carcinoma. Br J Dermatol 2008; 158(2): 261-5.

[19] Cotran RS, Kumar V, Abbas AK, Fausto N. Robbins e Cotran Patologia-Bases Patológicas das Doenças. $7^{\mathrm{a}}$ ed. Rio de Janeiro: Elsevier, 2005.

[20] Kruse AJ, Baak JPA, Jansen EA, et al. Ki-67 predicts progression in early CIN: Validation of a multivariate progression-risk model. Cell Oncol 2004; 26(1-2): 13-20.

[21] Harris TG, Kulasingam SL, Kiviat NB, et al. Cigarette smoking, oncogenic homan papilomavirus, Ki-67 antigen, and cervical intraepithelial neoplasia. Am J Epidemiol 2004; 159(9): 834-42.

[22] Cambruzzi E, Zettler CG, Alexandre COP. Expression of Ki-67 and squamous intraepithelial lesions are related with HPV in endocervical adenocarcinoma. Pathol Oncol Res 2005; 11(2): 114-20.
[23] Isacson C, Theodore DK, Hedrick L, Cho KR. Both cell proliferation and apoptosis increase with lesion grade in cervical neoplasia but do not correlate with human papillomavirus type. Cancer Res 1996; 56(2): 669-74.

[24] Kaplanis K, Kiziridou A, Liberis V, Destouni Z, Galazios G. Ecadherin expression during progression of squamous intraepithelial lesions in the uterine cervix. Eur J Gynaecol Oncol 2005; 26(6): 608-10.

[25] Bremnes RM, Veve R, Hirsch FR, Franklin WA. The E-cadherin cellcell adhesion complex and lung cancer invasion, metastasis and prognosis. Lung Cancer 2002; 36(2): 115-24.

[26] Yaldizl M, Hakverdi AU, Bayhan G, Akkuş Z. Expression of Ecadherin in squamous cell carcinomas of the cervix with correlations to clinicopathological features. Eur J Gynaecol Oncol 2005; 26(1): 95-8.

[27] Rosenau J, Bahar MJ, Wasiellewski R, et al. Ki-67, E-cadherin, and p53 as prognostic indicators of long-term outcome after liver transplation for metastatic neuroendocrine tumors. Transplantation 2002; 73(3): 386-94.

[28] Van de Putte G, Kristensen GB, Baekelandt M, Lie AK, Holm R. Ecadherin and Catenins in early squamous cervical carcinoma. Gynecol Oncol 2004; 94(2): 521-7.

[29] Roa IE, Villaseca M, Araya JC, Roa J, Aretxabala XU, Miranda M. Moléculas de adhesión celular y cancer. Rev Chil Cir 2001; 53(5): 50410 .

[30] Dursun P, Yuce K, Usubutun A, Ayhan A. Loss of epithelium cadherin expression is associated with reduced overall survival and disease-free survival in early-stage squamous cell cervical carcinoma. Int J Gynecol Cancer 2007; 17(4): 843-50.

[31] Volgareva G, Zavalishina L, Andreeva Y, et al. Protein p16 as a marker of dysplastic and neoplastic alterations in cervical epithelial cells. BMC Cancer 2004; 4: 58 .

[32] Tringler B, Gup CJ, Singh M, et al. Evaluation of p16INK4A and pRb expression in cervical squamous and glandular neoplasia. Hum Pathol 2004 ; 35(6): 689-96.

[33] Maehama T. Epidemiological study in Okinawa, Japan, of human papilomavírus infection of the uterine cervix. Infect Dis Obstet Gynecol 2005; 13(2): 77-80.

[34] Longato Filho A, Utagawa ML, Shiarata KN, et al. Immunocytochemical expression of p16INK4A and Ki-67 in cytologically negative and equivocal pap smears positive for oncogenic human papillomavirus. Int J Gynecol Pathol 2005; 24(2): 118-24.

[35] Walts AE, Lechago J, Bose S. P16 and Ki67 immunostaining is a useful adjunct in the assessment of biopsies for HPV-associated anal intraepithelial neoplasia. Am J Surg Pathol 2006; 30(7): 795-801.

[36] Vinh-Hung V, Bourgain C, Vlastos G, et al. Prognostic value of histopathology and trends in cervical cancer: a SEER population study. BMC Cancer 2007; 7: 164.

[37] Jemal A, Siegel R, Ward E, et al. Cancer statistics. CA Cancer J Clin 2008; 58(2): 71-96.

[38] Jain RV, Mills PK, Parikh-Patel A. Cancer incidence in the south Asian population of California. 1988-2000. J Carcinog 2005; 4: 21.

[39] Parkin DM, Bray FI, Devesa SS. Cancer burden in the year 2000. The global picture. Eur J Cancer 2001; 37(Suppl 8): S4-66.

[40] Rodriguez AC, Burk R, Herrero R, et al. The natural history of human papillomavirus infection and cervical intraepithelial neoplasia among young women in the guanacaste cohort shortly after initiation of sexual life. Sex Transm Dis 2007; 34(7): 494-502.

[41] Kahn JA, Lan D, Kahn RS. Sociodemographic factors associated with high-risk human papillomavirus infection. Obstet Gynecol 2007; 110(1): 87-95.

[42] Nakagawa, M, Kim KH, Gillam TM, Moscicki AB. HLA Class I binding promiscuity of the CD8 T-cell epitopes of human papillomavirus type 16 E6 protein. J Virol 2007; 81(3): 1412-23.

[43] Meijer CJ. Detection of HPV in cervical scrapes by PCR in relation to cytology: Possible implications for cancer screening. In: Munoz N, Bosh FX, Shan KV, Eds. The epidemiology of HPV and cervical cancer. Lyon: IARC Scientific Publications 1992; pp. 271-81.

This is an open access article licensed under the terms of the Creative Commons Attribution Non-Commercial License (http: //creativecommons.org/licenses/by-nc/ $3.0 /$ ) which permits unrestricted, non-commercial use, distribution and reproduction in any medium, provided the work is properly cited. 